\title{
The role of the hierarchical theory in explaining the capital structure of the firms based on enterprise life cycle model
}

\author{
Jamal Bahiri Saleth $^{a^{*}}$ and Abbas Aalizadeh ${ }^{\mathrm{b}}$
}

${ }^{a}$ Assistant Professor, Accounting Group, Oroumieh Branch, Islamic Azad University, Oroumieh, Iran ${ }^{b}$ PhD Student, Assistant Professor, Accounting Group, Oroumieh Branch, Islamic Azad University, Oroumieh, Iran

\begin{tabular}{l}
\hline C H R O N I C L E \\
\hline Article history: \\
Received December 5, 2015 \\
Received in revised format \\
February 162016 \\
Accepted May 242016 \\
Available online \\
May 25 2016 \\
Keywords: \\
Tehran Stock Exchange \\
The hierarchical theory \\
Growth \\
Life cycle
\end{tabular}

\section{Introduction}

Capital structure is a controversial issue in the field of corporate finance. There are several studies to find a way to determine the optimal capital structure to minimize the cost of capital and maximize the corporate value. In fact, capital structure is a combination of firms' liabilities and capital to meet long term assets. Ball et al. (2015) demonstrated that cash-based operating profitability could outperform measures of profitability including accruals. In addition, cash-based operating profitability could subsume accruals in forecasting the cross section of average returns. Any investor may increase a strategy's Sharpe ratio more by contributing just a cash-based operating profitability factor to the investment opportunity set than by adding both an accruals factor and a profitability factor, which incorporates accruals. Keefe and Yaghoubi (2016) explored the relationship between capital structure and firm cash flow volatility using various measures of a firm's cash flow volatility. They reported that ceteris paribus a one standard deviation could possibly increase from the mean of cash flow volatility.

* Corresponding author.

E-mail address: bahrisls.J@gmail.com (J. Bahiri Saleth)

C 2017 Growing Science Ltd. All rights reserved. doi: 10.5267/j.ac.2016.5.001 
Jensen (1986) forecasted that managers with more free cash flows (FCF) available indicate an opportunistic attitude, which could possibly lead to the emergence of the FCF risk. Therefore, detecting the relative importance of factors influencing on the FCF risks appears to be important. Namazi et al. (2015) examined Jensen's assertion by detecting relative importance of the factors affecting FCF risks via artificial neural network (ANN). They considered seven independent variables relating to FCF risks including debt policy, ownership concentration, ownership level, managerial ownership, state ownership, size of the firm, and profitability. They collected 1224 company-year data from Tehran Stock Exchange (TSE) over the period 2001-2010. They reported that, among the preceding 7 factors, profitability was the most important factor in detecting FCF risks followed by debt policy and size of the firms. The finding appeared a great implication for the stock markets and contradicts Jensen's (1986) study.

Chen et al. (2015) investigated whether and how free cash flow and corporate governance characteristics could possibly influence on firm level investments, based on 865 Chinese listed companies. They reported that firms' over-investment was more sensitive to current free cash flow and that over-investment was more pronounced in firms with positive free cash flows, which was consistent with the agency cost explanation. In addition, they reported that certain corporate governance characteristics were substantially associated with firm level investment. Moreover, they divided the full sample into two subsamples of over and under investment companies. For over-investment companies, their evidence indicated that higher state-ownership concentration could possibly boost overinvestment, while companies with higher proportion of tradable shares, larger board size of supervisors or higher leverage mitigate over-investment. For under-investment companies, their evidence indicated that companies with higher state-ownership concentration, larger board size of directors or higher proportion of outside directors were associated with severer under-investment, while companies with higher leverage or higher proportion of tradable shares influence on under-investment.

Aharony et al. (2006) investigated the value relevance of the entire set of the cash flow summary information measures reported in the Statement of Cash Flows relative to their corresponding three summary accrual accounting measures, separately for each of three firm lifecycle stages. They reported that the power of the cash flow information set to describe concurrent return on the firm's equity was not substantially different from that of the accrual accounting set. Antoniou et al. (2008) studied how companies operating in capital market-oriented economies and bank-oriented economies determine their capital structure. They reported that the leverage ratio was positively influenced by the tangibility of assets and the size of the firm, but declined with an increase in company profitability, growth opportunities, and share price performance in both kinds of economies.

Bowen et al. (1982) provided some evidences on the relationship between accounting leverage measures and industrial classifications. Bradley et al. (1984) provided some insights about optimal capital structure. Chen (2004) discussed on determinants of capital structure of Chinese-listed companies. Degryse et al. (2012) investigated the effect of firm and industry characteristics on small firms' capital structure, employing a proprietary database containing financial statements of Dutch small and medium-sized enterprises (SMEs).

\section{The proposed study}

This paper investigates the role of the hierarchical theory in explaining the capital structure of the firms based on enterprise life cycle model on selected firms listed on Tehran Stock Exchange (TSE) using three methods of net equities, net liabilities and retained earnings. The study uses Park and Chen's (2006) method to categorize the life cycle of 81 randomly selected firms from TSE over the period 2007-2012. The proposed study of this paper considers the following three hypotheses, 
First hypothesis: The hierarchical theory plays important role in explaining the capital structure of the firms during the growth cycle.

The main hypothesis of this survey consists of the following two sub-hypotheses,

1. During the growth period, deficit funding has an impact on net debt.

2. During the growth period, deficit funding has an impact on net equity.

Second hypothesis: The hierarchical theory plays important role in explaining the capital structure of the firms during the maturity cycle.

The main hypothesis of this survey consists of the following two sub-hypotheses,

1. During the maturity period, deficit funding has an impact on net debt.

2. During the maturity period, deficit funding has an impact on net equity.

Third hypothesis: The hierarchical theory plays important role in explaining the capital structure of the firms during the declining cycle.

The main hypothesis of this survey consists of the following two sub-hypotheses,

1. During the declining period, deficit funding has an impact on net debt.

2. During the declining period, deficit funding has an impact on net equity.

To examine the first hypothesis, we use the following relationship,

$$
N E I_{i, t}=C+\beta_{1}\left(\text { Deficit }_{i, t}\right)+\beta_{2}\left(\operatorname{SZIE}_{i, t}\right)+\beta_{3}\left(P_{i, t}\right)+\beta_{4}\left(G_{i, t}\right)+\beta_{5}\left(L_{i, t}\right)+\varepsilon_{i, t} .
$$

And to examine the second and the third hypotheses we use the following relationship,

$$
N D I_{i, t}=C+\beta_{1}\left(\text { Deficit }_{i, t}\right)+\beta_{2}\left(\operatorname{SZIE}_{i, t}\right)+\beta_{3}\left(P_{i, t}\right)+\beta_{4}\left(G_{i, t}\right)+\beta_{5}\left(L_{i, t}\right)+\varepsilon_{i, t}
$$

where $N D I_{i, t}$ and $N E I_{i, t}$ represent the first difference of debt and first difference of book equity, respectively. In addition, $C$, Deficitit, $, S S I Z E_{i, t}, P_{i, t}, G_{i, t}$ and $L_{i, t}$ represent intercept, cash flow deficit, size of the firm, profitability, growth opportunities and liquidity, respectively. In both models, $\beta_{1}$ to $\beta_{5}$ are coefficients to be estimated and $\varepsilon_{i, t}$ represents residuals.

In our study, growth opportunity is calculated as assets growth of firm $i$ in year $t$ compared with the previous year. $L_{i t}=$ financial liquidity of firm $i$ in year $t$. Deficit $t_{i, t}=$ cash deficit is the excess of cash disbursements over cash receipts in any given fiscal period. $P_{i, t}=$ Profit growth of firm $i$ in year $t$, compared with the previous year. Finally, $S S I Z E_{i, t}=$ represent the size of the firm and it is calculated by taking natural logarithm of total assets.

\section{Research results}

\subsection{Testing the hypotheses during the growth cycle}

The first hypothesis investigates whether or not the hierarchical theory plays important role in explaining the capital structure of the firms during the growth cycle. Table 1 demonstrates the results of the survey. 
Table 1

The summary of testing the first hypothesis

\begin{tabular}{|c|c|c|c|}
\hline Variable & Coefficient & t-value & Prob. \\
\hline Intercept & 0.161 & 0.925 & 0.357 \\
\hline Cash deficit $\left(\beta_{1}\right)$ & -0.038 & -1.011 & 0.314 \\
\hline Firm size $\left(\beta_{2}\right)$ & 0.003 & 0.260 & 0.794 \\
\hline Profitability $\left(\beta_{3}\right)$ & -0.222 & -1.983 & 0.046 \\
\hline Growth opportunity $\left(\beta_{4}\right)$ & -0.012 & -2.397 & 0.018 \\
\hline Liquidity $\left(\beta_{5}\right)$ & -0.125 & -1.832 & 0.070 \\
\hline
\end{tabular}

As we can observe from the results of Table 1, F-value is equal to 3.169 which is meaningful when the level of significance is five percent. This means the relationship between independent variables and dependent variable is linear. Durbin-Watson is within the acceptable level, which means there is no correlations among the residuals and other statistics are also within desirable levels. The coefficient of cash deficit is not statistically significant, which means the first sub-hypothesis cannot be confirmed. To examine the sub-hypotheses of the survey, we use Eq. (2) and Table 2 summarizes the results of our survey.

\section{Table 2}

The summary of testing the first sub-hypothesis

\begin{tabular}{|c|c|c|c|}
\hline Variable & Coefficient & t-value & Prob. \\
\hline Intercept & 0.175 & 1.949 & 0.054 \\
\hline Cash deficit $\left(\beta_{1}\right)$ & 0.023 & 1.153 & 0.251 \\
\hline Firm size $\left(\beta_{2}\right)$ & -0.012 & -1.970 & 0.044 \\
\hline Profitability $\left(\beta_{3}\right)$ & 0.123 & 2.082 & 0.040 \\
\hline Growth opportunity $\left(\beta_{4}\right)$ & -0.001 & -0.465 & 0.642 \\
\hline Liquidity $\left(\beta_{5}\right)$ & 0.155 & 4.401 & 0.000 \\
\hline
\end{tabular}

As we can observe from the results of Table 2, F-value is equal to 5.951 which is meaningful when the level of significance is five percent. This means the relationship between independent variables and dependent variable is linear. Durbin-Watson is within the acceptable level, which means there is no correlations among the residuals and other statistics are also within desirable levels. The coefficient of cash deficit is not statistically significant, which means the second sub-hypothesis cannot be confirmed.

\subsection{Testing the hypotheses during the maturity cycle}

The first hypothesis investigates whether or not the hierarchical theory plays important role in explaining the capital structure of the firms during the maturity cycle. Table 3 demonstrates the results of the survey.

Table 3

The summary of testing the first hypothesis

\begin{tabular}{lccc}
\hline Variable & Coefficient & t-value & Prob. \\
\hline Intercept & 0.098 & 1.191 & 0.234 \\
Cash deficit $\left(\beta_{1}\right)$ & 0.079 & 3.157 & 0.002 \\
Firm size $\left(\beta_{2}\right)$ & 0.001 & 0.241 & 0.809 \\
Profitability $\left(\beta_{3}\right)$ & 0.168 & -2.884 & 0.004 \\
Growth opportunity $\left(\beta_{4}\right)$ & -0.004 & -1.971 & 0.042 \\
Liquidity $\left(\beta_{5}\right)$ & -0.138 & -2.735 & 0.006 \\
\hline $\mathrm{F}=8.311(0.011)$, Durbin-Watson $=1.936$, Breusch-Godfrey $=0.356(0.700)$, White $\mathrm{H}=1.396(0.120)$, Adj. $\mathrm{R}^{2}=0.312$
\end{tabular}

As we can observe from the results of Table 3, F-value is equal to 9.311 which is meaningful when the level of significance is five percent. This means the relationship between independent variables and dependent variable is linear. Durbin-Watson is within the acceptable level, which means there is no 
correlations among the residuals and other statistics are also within desirable levels. The coefficient of cash deficit is statistically significant, which means the first sub-hypothesis cannot be rejected and there is a positive and meaningful relationship between cash deficit and net liabilities. To examine the subhypotheses of the survey, we use Eq. (2) and Table 4 summarizes the results of our survey.

\section{Table 4}

The summary of testing the second sub-hypothesis

\begin{tabular}{|c|c|c|c|}
\hline Variable & Coefficient & t-value & Prob. \\
\hline Intercept & -0.02 & -0.341 & 0.729 \\
\hline Cash deficit $\left(\beta_{1}\right)$ & 0.045 & 2.544 & 0.011 \\
\hline Firm size $\left(\beta_{2}\right)$ & 0.001 & 0.434 & 0.664 \\
\hline Profitability $\left(\beta_{3}\right)$ & -0.002 & -0.062 & 0.050 \\
\hline Growth opportunity $\left(\beta_{4}\right)$ & -0.001 & -0.881 & 0.378 \\
\hline Liquidity $\left(\beta_{5}\right)$ & 0.099 & 2.787 & 0.005 \\
\hline
\end{tabular}

As we can observe from the results of Table 4, F-value is equal to 3.942 which is meaningful when the level of significance is five percent. This means the relationship between independent variables and dependent variable is linear. Durbin-Watson is within the acceptable level, which means there is no correlations among the residuals and other statistics are also within desirable levels. The coefficient of cash deficit is statistically significant, which means the second sub-hypothesis cannot be rejected and there is a positive and meaningful relationship between the cash deficit and dependent variable.

\subsection{Testing the hypotheses during the declining cycle}

The first hypothesis investigates whether or not the hierarchical theory plays important role in explaining the capital structure of the firms during the declining cycle. Table 5 demonstrates the results of the survey.

\section{Table 5}

The summary of testing the first hypothesis

\begin{tabular}{|c|c|c|c|}
\hline Variable & Coefficient & t-value & Prob. \\
\hline Intercept & 0.097 & 0.640 & 0.523 \\
\hline Cash deficit $\left(\beta_{1}\right)$ & 0.025 & 0.430 & 0.668 \\
\hline Firm size $\left(\beta_{2}\right)$ & -0.004 & -0.382 & 0.702 \\
\hline Profitability $\left(\beta_{3}\right)$ & 0.013 & 0.090 & 0.928 \\
\hline Growth opportunity $\left(\beta_{4}\right)$ & 0.001 & 0.037 & 0.970 \\
\hline Liquidity $\left(\beta_{5}\right)$ & -0.014 & -0.095 & 0.023 \\
\hline
\end{tabular}

As we can understand from the results of Table 5, F-value is equal to 0.101 which is not meaningful when the level of significance is five percent. This means the relationship between independent variables and dependent variable is not linear. Durbin-Watson is within the acceptable level, which means there is no correlations among the residuals and other statistics are not within desirable levels. The coefficient of cash deficit is not statistically significant, which means the first sub-hypothesis cannot be accepted and there is no meaningful relationship between cash deficit and net liabilities. To examine the sub-hypotheses of the survey, we use Eq. (2) and Table 6 summarizes the results of our survey.

Table 6

The summary of testing the second sub-hypothesis

\begin{tabular}{|c|c|c|c|}
\hline Variable & Coefficient & t-value & Prob. \\
\hline Intercept & 0.004 & 0.084 & 0.933 \\
\hline Cash deficit $\left(\beta_{1}\right)$ & 0.014 & 0.755 & 0.451 \\
\hline Firm size $\left(\beta_{2}\right)$ & 0.006 & 0.171 & 0.846 \\
\hline Profitability $\left(\beta_{3}\right)$ & -0.090 & -1.960 & 0.053 \\
\hline Growth opportunity $\left(\beta_{4}\right)$ & 0.002 & 1.096 & 0.275 \\
\hline Liquidity $\left(\beta_{5}\right)$ & 0.036 & 0.771 & 0.442 \\
\hline
\end{tabular}


As we can see from the results of Table 6, F-value is equal to 1.078 which is not meaningful when the level of significance is five percent. This means the relationship between independent variables and dependent variable is not linear. Durbin-Watson is within the acceptable level, which means there is no correlations among the residuals and other statistics are not within desirable levels. The coefficient of cash deficit is not statistically significant, which means the first sub-hypothesis cannot be accepted and there is no meaningful relationship between cash deficit and net liabilities.

\section{Conclusion}

We have studied the role of the hierarchical theory in explaining the capital structure of the firms based on enterprise life cycle model on selected firms listed on Tehran Stock Exchange (TSE) using three methods of net equities, net liabilities and retained earnings. The study uses Park and Chen's (2006) method to categorize the life cycle of 81 randomly selected firms from TSE over the period 2007-2012. The results have indicated that the hierarchical theory represents the growing firms better than the matured firms. The results also have shown that firms were more willing to reduce their dividend per share for financing their projects.

\section{Acknowledgement}

The authors would like to thank the anonymous referees for constructive comments on earlier version of this paper.

\section{References}

Aharony, J., Falk, H., \& Yehuda, N. (2006). Corporate life cycle and the relative value-relevance of cash flow versus accrual financial information.2003-07-15)[2008-08-30]. http://Www. Bus. Brocku. Ca/Faculty/Documents/Corporate-Life-Cycle.Pdf.

Antoniou, A., Guney, Y., \& Paudyal, K. (2008). The determinants of capital structure: capital marketoriented versus bank-oriented institutions. Journal of financial and quantitative analysis, 43(01), 59-92.

Ball, R., Gerakos, J., Linnainmaa, J. T., \& Nikolaev, V. V. (2015). Accruals, cash flows, and operating profitability in the cross section of stock returns. Chicago Booth Research Paper, (15-12).

Bowen, R. M., Daley, L. A., \& Huber Jr, C. C. (1982). Evidence on the existence and determinants of inter-industry differences in leverage.Financial Management, 11(4), 10-20.

Bradley, M., Jarrell, G. A., \& Kim, E. (1984). On the existence of an optimal capital structure: Theory and evidence. The Journal of Finance, 39(3), 857-878.

Chen, J. J. (2004). Determinants of capital structure of Chinese-listed companies. Journal of Business research, 57(12), 1341-1351.

Chen, X., Sun, Y., \& Xiaodong, X. U. (2015). Free Cash Flow, Over-Investment and Corporate Governance in China. Pacific-Basin Finance Journal, 37, 81-103.

Degryse, H., de Goeij, P., \& Kappert, P. (2012). The impact of firm and industry characteristics on small firms' capital structure. Small Business Economics, 38(4), 431-447.

Keefe, M. O. C., \& Yaghoubi, M. (2016). The influence of cash flow volatility on capital structure and the use of debt of different maturities. Journal of Corporate Finance, 38, 18-36.

Jensen, M. C. (1986). Agency cost of free cash flow, corporate finance, and takeovers. Corporate Finance, and Takeovers. American Economic Review,76(2), 323-329.

Namazi, M., Shokrolahi, A., \& Maharluie, M. S. (2015). Detecting and ranking cash flow risk factors via artificial neural networks technique. Journal of Business Research, 69(5), 1801-1806

Park, Y., \& Chen, K. H. (2006). The effect of accounting conservatism and life-cycle stages on firm valuation. Journal of Applied Business Research (JABR), 22(3), 75-92. 